\title{
Madrasah Nizamiyah: Telaah Historis Sebagai Lembaga Pendidikan dan Perang Politik-Ideologi
}

\author{
Mahfud Ifendi \\ Manajemen Pendidikan Islam, Jurusan Tarbiyah, STAI Sangatta Kutai Timur \\ Email: mahfudzifindi@gmail.com
}

Received: July 12, 2020 | Accepted: December 9, 2020

\begin{abstract}
As we know, Nizamiyah madrasas have played an important role in the history of Islamic civilization to sustain the pace of development of Islamic education. This article aims to describe the history of the establishment of the Nizamiyah madrasah as an educational institution and the chaotic establishment of this madrasa because it has rubbed off against political-ideological elements. This type of research is a qualitative research. In accordance with the object of the study of this article, this type of research is included in the category of library research. The result in this article is that the Nidhomiyah madrasa was founded in $447 \mathrm{H} / 1055 \mathrm{M}$ under the leadership of Tughril Bek from the Snowq dynasty. However, the main figure in the establishment of this madrasa was its vizier named Nizam al-Mulk. As an educational institution, of course this madrasah is the same as other madrasas in terms of management, educators, students, and learning methods. However, in terms of curriculum, this madrasah is a bit different because it contains Ashariyah theology material which is the main objective to defend the Sunni ideology of the Shia-Mu'tazilah ideology. After all, apart from having a role as an educational institution, this Nizamiyah madrasah cannot be separated from the realm of the politics-ideology that underlies its birth.
\end{abstract}

\begin{abstract}
Abstrak
Sebagaimana yang kita ketahui, madrasah Nizamiyah telah memainkan peran penting dalam sejarah peradaban Islam untuk menopang laju perkembangan pendidikan Islam. Artikel ini bertujuan untuk menguraikan sejarah berdirinya madrasah Nizamiyah sebagai lembaga pendidikan dan carut marut berdirinya madrasah ini karena telah bergesekan dengan unsur politik-ideologi. Jenis Penelitian ini merupakan penelitian kualitatif. Sesuai dengan obyek kajian artikel ini, maka jenis penelitian ini termasuk dalam kategori penelitian kepustakaan (library research). Hasil dalam artikel ini adalah bahwa madrasah Nidhomiyah berdiri pada tahun 447 H/1055 M di bawah kepemimpinan Tughril Bek dari dinasti Saljuq. Namun yang menjadi tokoh utama dalam berdirinya madrasah ini adalah wazirnya yang bernama Nizam al-Mulk. Sebagai lembaga pendidikan tentunya madrasah ini sama seperti halnya madrasah yang lain dilihat dari sisi manajemen, pendidik, peserta didik, dan metode pembelajaran. Namun dari sisi kurikulum, pada madrasah ini agak sedikit berbeda karena didalamnya terdapat materi teologi Asy'ariyah yang memang tujuan utamanya adalah untuk mempertahankan ideologi sunni dari idelogi Syiah-Mu’tazilah. Bagaimanapun juga, selain memiliki peran sebagai lembaga
\end{abstract}


pendidikan, madrasah Nizamiyah ini tak bisa lepas dari ranah politik-ideologi yang melatarbelakangi kelahirannya.

\section{Keywords}

Nizamiyah, educational institutions, political-ideology

\section{Pendahuluan}

Puncak kemajuan pembelajaran Islam berhubungan erat dengan kemajuan peradaban Islam. Beberapa tokoh sejarah peradaban Islam, semacam Harun Nasution menuturkan jika puncak kejayaan kekuasaan Islam berlangsung antara tahun 650-1000. Kemajuan peradaban Islam pada fase mula-mula tidak cuma berlangsung dalam bidang politik, tapi jua dalam bidang ilmu pengetahuan serta pemikiran Islam. Pokok kemajuan Islam berlangsung sesudah terdapatnya kontak antara peradaban Islam dengan peradaban Yunani (Misdar, 2017; Wijdan, 2007). Salah satu penanda masa kejayaan pendidikan Islam merupakan dengan berkembangnya bermacam lembaga pembelajaran Islam, yang pastinya perihal ini hendak pengaruhi pola pikir warga serta pola kehidupan, sosial budaya umat Islam (Kodir, 2015).

Luasnya daerah kekuasaan Islam akibat dari perluasan yang diiringi dengan dakwah ajaran buat memeluk agama Islam kepada warga/ bangsa supaya Islam dijadikan bagaikan pedoman hidup baik yang berhubungan vertikal ataupun horizontal. Mereka merupakan para teman, baik yang jadi anggota pasukan perluasan ataupun orang-orang opsi tertentu yang memanglah diseleksi buat membimbing, membina serta mendidik warga supaya ingin menekuni Islam. Hingga di luar Madinah, di pusat wilayah-wilayah yang baru dikuasai, berdirilah pusatpusat pembelajaran di bawah pengurusan para sahabat yang setelah itu dibesarkan oleh para penggantinya (tabi'in) serta seterusnya. Di pusat-pusat pembelajaran tersebut, para sahabat membagikan pelajaran agama Islam kepada para muridnya, baik yang berasal dari penduduk setempat ataupun yang tiba dari wilayah lain. Di pusat-pusat pembelajaran tersebut, timbullah madrasah-madrasah, yang masih berbentuk suatu tempat buat membagikan pelajaran agama dalam wujud halaqah di masjid ataupun tempat pertemuan yang lain(Zuhairini, Moh. Kasiram, Abdul Ghofir, Tajdab, 2013).

Dengan demikian, madrasah pada hakikatnya telah sempat terdapat di era para sahabat. Tetapi keberadaannya belum se-formal serta se-komplit pada masa-masa sesudahnya. Madrasah dikala itu ialah pengganti kedudukan masjid yang dikala itu partisipan belajarnya membludak, sebab semangat belajar umat Islam yang begitu besar, sehingga masjid tidak sanggup lagi menampung orang-orang yang mau belajar serta lambat laun kegiatan yang semacam ini hendak mengusik kekhusukan orang yang lagi shalat di masjid. Kesimpulannya madrasah jadi suatu pemecahan buat menuntaskan permasalahan tersebut yang menggambarkan bentuk kelanjutan dari aktivitas ataupun kegiatan belajar yang dilakukan di masjid (Daulay, 2007).

Pertumbuhan berikutnya pada masa dinasti Umayyah, pola-pola pembelajaran serta pusat-pusat pembelajaran lebih baik serta lebih sistematis bila dibanding dengan era tadinya. Sampai kesimpulannya kemajuan serta puncak kejayaan itu terdapat pada masa dinasti Abbasiyah yang jadi penanda kemajuan umat Islam secara totalitas. Pada periode kedua dari pemerintahan dinasti Abbasiyah dikira bagaikan masa kemunduran serta disintegrasi; terhitung semenjak masa pemerintahan khalifah al-Mutawakkil hingga berakhirnya masa pemerintahan dinasti Abbasiyah dengan tumbangnya kota Baghdad ke tangan Hulagu Khan pada tahun 656 
H (1258 M). Masa kemunduran ini diisyarati dengan beralihnya sistem pemerintahan dari sentralisasi jadi desentralisasi, serta dengan timbulnya bangsa-bangsa baru dalam kancah pemerintahan dinasti Abbasiyah di Baghdad (Mahmud dan al-Syarif, 1997).

Di antara dinasti-dinasti baru yang pernah bermunculan pada waktu itu yakni dinasti Saljuq yang mengambil alih peran dinasti Buwaihi di dalam istana para khalifah Abbasiyah. Pada masa pemerintahan dinasti Saljuq inilah nantinya hendak timbul suatu lembaga pembelajaran berbentuk madrasah; Nizamiyah, yang bila dikala ini merupakan setara dengan pendidikan tinggi. Meski secara historisnya, kemunculan madrasah ini banyak perdebatan, namun dalam artikel ini yang menjadi fokus pembahasannya adalah bagaimana kemudian madrasah Nizamiyah ini menjadi lembaga pendidikan dan sebagai benteng untuk mempertahankan ideologi sunni yang ditekuni oleh para khalifahnya. Dengan memakai pendekatan sosio-historis, di dalam artikel ini hendak ditelusuri kelahiran madrasah Nizamiyah, sebagai lembaga pembelajaran serta selaku media untuk mempertahankan ajaran Sunni dari pandangan hidup yang lain misalnya Syi' ah serta Mu' tazilah.

Secara ḥarfiah, kata madrasah berasal dari bentuk Fi’il Madhī "Darasa” yang artinya belajar. Berdasarkan pengertian kebahasaan ini, maka setiap tempat yang digunakan untuk kegiatan belajar mengajar, seperti rumah, masjid, majelis taklim, langgar, surau, dan lainnya, dapat disebut dengan istilah madrasah. Adapun secara istilah (kesepakatan para pakar), Madrasah adalah merupakan tempat secara khusus untuk menyelenggarakan kegiatan belajar mengajar. Ia disamakan dengan istilah sekolah dalam konteks Indonesia, hal ini dapat dilihat dalam UndangUndang Sistem Pendidikan Nasional No 20 tahun 2003 (Mahfud Ifendi, 2017). Padanan madrasah dalam bahasa Indonesia adalah sekolah lebih dikhususkan lagi sekolah-sekolah agama Islam (Daulay, 2007).

Fatah Yasin menambahkan bahwa madrasah mengandung arti tempat atau wahana anak dalam melaksanakan proses pembelajaran. Maksudnya di madrasah itulah anak akan menjalani proses belajar secara terarah, terpimpin dan terkendali. Dengan demikian, secara teknis madrasah menggambarkan proses pembelajaran secara formal tidak berbeda dengan sekolah. Hanya dalam lingkup kultural, madrasah memiliki konotasi spesifik. Di lembaga ini anak memperoleh pembelajaran hal ihwal atau seluk-beluk agama dan keagamaan, dan ilmu-ilmu lain yang diperlukan oleh peserta didik sesuai dengan tuntutan kehidupan bermasyarakat, berbangsa dan bernegara, meskipun pada awalnya madrasah dikenal hanya sebagai wahana tempat mempelajari ilmu-ilmu keagamaan (Yasin, 2008).

Artinya madrasah pada awal kemunculannya merupakan lembaga pendidikan yang bercirikan Islam yang di dalamnya hanya diajarkan materi-materi keagamaan atau syariah saja. Namun dalam tahap perkembangannya madrasah juga tak menutup diri, yakni dengan memasukkan atau menambahkan mata pelajaran ilmu-ilmu umum sebagai bentuk penyempurnaan kurikulum yang telah dipelajari di madrasah. Apalagi pada masa pembaruan pendidikan, materi-materi pelajaran yang umum dimasukkan dalam kurikulum di semua lembaga pendidikan. Harapannya adalah dengan dimasukkannya materi pelajaran umum, nantinya akan menjadi bekal anak yang semakin komplit di kemudian hari. Mengingat tantangan zaman selalu berubah-ubah sesuai dengan tuntutan waktu yang terus berjalan.

Madrasah adalah lembaga pendidikan Islam yang tumbuh setelah masjid. Salah satu faktor yang menyebabkan tumbuhnya madrasah adalah karena masjid-masjid telah penuh dengan tempat-tempat belajar dan hal ini sangat mengganggu aktifitas pelaksanaan ibadah shalat (Daulay, 2007). Madrasah Nizamiyah merupakan madrasah terbesar pertama yang dikelola pada 
masa pemerintahan dinasti Saljuq (Ahmad, 2015). Madrasah ini didirikan oleh perdana menteri (wazir) Ghawam al-Din Abu 'Ali Hasan ibn Ishaq Khauja, yang dikenal dengan panggilan akrab Nizam al-Mulk. Madrasah ini dapat disamakan dengan pendidikan tinggi masa sekarang. Madrasah ini merupakan perguruan tinggi Islam yang menjadi model bagi lembaga pendidikan tinggi yang didirikan pada masa itu (Ramayulis, 2011). Di madrasah inilah al-Ghazaly memberikan kuliahnya selama empat tahun (1091-1095 M), dan pernah menjadi dekan di madrasah ini (Phillip. K. Hitti, 2002).

Nizam al-Mulk, wazir dinasti Saljuq, sudah membangun sebagian madrasah yang dilengkapi dengan taman pustaka dengan beberapa dana abadi sebagai sumber dana (Ta'rifin, 2010). Madrasah-madrasah yang didirikan oleh Nizam al-Mulk diucap sebagai madrasah Nizamiyah, sesuatu penamaan yang menisbatkan nama pendirinya. Kemasyhuran madrasah ini sangat diketahui di segala daerah Islam. Keberadaannya bisa ditemui nyaris di tiap kota, antara lain di Baghdad, Balk, Naisabur, Herat( Iran), Basrah, Isfahan, Merv, Mosul( Irak) serta sebagainya (Mahmud Yunus, 1990). Pertumbuhan madrasah ini tidak dapat dilepaskan dari kedudukan aktif Nizam al-Mulk. Mulanya dia cuma membangun sebagian madrasah. Setelah itu, jikalau dia bepergian serta di dalam perjalananya tadi berjumpa dengan orang yang mempunyai ilmu pengetahuan yang luas, hingga di wilayah seperti itu didirikan madrasah yang baru. Orang yang ditemuinya setelah itu dinaikan sebagai tenaga pendidik.

Dari sekian banyak madrasah, madrasah Nizamiyah di Baghdad ialah yang populer serta yang terbesar. Madrasah ini terletak di pinggir sungai Dajlah (Tirgis), di tengah-tengah pasar Selasa di Baghdad, serta dibentuk antara tahun 457 H/ 1065 M sampai tahun 459 H/ 1067 M. Orang-orang yang diresmikan selaku pengajar antara lain yaitu Abu Ishaq al-Syirazi (w. $476 \mathrm{H}$ / 1083 M), Abu Nasr al-Sabbagh (w. 477 H/ 1084 M), Abu al-Qasim al-' Alawi (w. 482 h/ 1089 M), Abu Abdillah al-Tabari (w. 495 H/ 1101 M), Abu Hamid al-Ghazali (w. 505 H/ 1111 M), al-Qazwaini (w. 575 H/ 1179 M) serta Fairuzzabadi (w. 817 H/ 1414 M). Bagi Montgomery Watt, al-Imam al-Haramain al-Juwaini sempat berprofesi selaku pimpinan madrasah Nizamiyah sampai wafatnya di tahun $1085 \mathrm{M}$. Memandang para pengajar di atas, bisa dikatakan kalau madrasah Nizamiyah merupakan madrasah fiqih, dan bukan madrasah filsafat. Terlebih bila diingat kalau era itu ialah era penindasan filsafat serta filosofnya(Idi, 2006).

\section{Metode}

Jenis Penelitian ini merupakan penelitian kualitatif (Nasution, 1988). Sesuai dengan obyek kajian artikel ini, maka jenis penelitian ini termasuk dalam kategori penelitian kepustakaan (library research). Menurut Kaelan, dalam penelitian kepustakaan kadang memiliki deskriptif dan juga memiliki ciri historis (Kaelan, 2010). Teknik pengumpulan data, dalam hal ini penulis melakukan identifikasi wacana dari buku-buku, makalah atau artikel, majalah, jurnal, web (internet), ataupun informasi lainnya yang berhubungan dengan judul penulisan untuk mencari hal-hal atau variabel yang berupa catatan, transkip, buku, surat kabar, majalah dan sebagainya yang berkaitan dengan kajian tentang madrasah Nizamiyah.

\section{Hasil dan Pembahasan}

Kurikulum Madrasah Nizamiyah

Kaitannya dengan kurikulum, belum ada kesepakatan secara bersama dalam hal menentukan kebijakan kurikulum karena setiap madrasah mempunyai kebebasan untuk menentukan kurikulumnya sendiri. Secara umum dapat diakatakan bahwa madrasah Nizamiyah 
ini materi kurikulumnya lebih berorientasi pada hukum Islam sesuai dengan misi didirikannya madrasah ini. Namun ini belum berarti bahwa materi lain tidak diberikan. Oleh Makdisi disebutkan bahwa materi utama yang diberikan di madrasah ini adalah al-Qur'an, hadits, ulum al-Qur'an, tafsir, fiqih, ushul fiqih, dan materi keagamaan lain yang terkait. Oleh Albert Hourani dikatakan lembaga pendidikan Islam ini didirikan untuk mengajarkan al-Qur'an dan hadits tetapi sebagian besar lembaga pendidikan madrasah yang ada tujuan utamanya adalah mengajarkan fiqih (Darwis, 2010).

Memperbanyak penjelasan apa yang di informasikan oleh Djamaludin Darwis, Suwito berkata kenapa ilmu-ilmu ke-alaman ( fisika, kimia, astronomi) serta medis tidak dimasukkan dalam kurikulum pembelajaran madrasah Nizamiyah. Mengingat motif utama pendirian madrasah Nizamiyah ini merupakan berangkat dari ranah politik serta perang politik-ideologi, sehingga terdapat kemungkinan kalau materi-materi di atas tidak dimasukkan ke dalam kurikulum madrasah sebab memanglah tidak begitu dibutuhkan dalam rangka menunjang kepentingan politik serta ideologi penguasa waktu itu (Suwito \& Fauzan, 2005).

Menurut Mahmud Yunus, rencana pengajaran di madrasah Nizamiyah pada saat itu tidak diketahui dengan jelas. Namun bisa dikatakan bahwa kurikulum madrasah Nizamiyah pada saat itu didominasi oleh ilmu-ilmu agama atau ilmu-ilmu syari'ah. Bukti-buktinya adalah: (1) Tidak terdapat seseorang pula ahli-ahli sejarah yang berkata kalau di antara materi pelajaran yang dianjurkan di madrasah Nizamiyah merupakan ilmu medis, falak, serta ilmu tentu. Namun mereka cuma mengatakan kalau diantara modul pelajarannya merupakan nahwu, ilmu kalam, serta ilmu fiqih. (2) Guru-guru yang mengajar di madrasah nizhamiyah merupakan ulama-ulama syari' ah semacam Abu Ishaq al-Syarazi, al-Ghazali, al-Qazwaini, ibn al-Jauzi serta lain-lain. Tidak dikatakan kalau di situ pula tidak terdapat guru filsafat. Hingga madrasah Nizamiyah itu merupakan madrasah syari' ah bukan madrasah filsafat. (3) Pendiri madrasah Nizamiyah itu tidaklah orang yang membela filsafat serta bukan pula orang yang menolong pembebasan filsafat. (4) Era berdirinya madrasah Nizamiyah tidaklah era keemasan filsafat melainkan era penindasan terhadap filsafat (Mahmud Yunus, 1990).

Sedikit berbeda dengan Mahmud Yunus, menurut Mahmud Hasan Bilqrami berkata kalau pelajaran yang diberikan di madrasah Nizamiyah, pula mencakup ilmu bahasa tradisional. Fiqih, kajian-kajian Islam, ilmu hisab, faraid, riset tanah, sejarah sastra, kesehatan, metode memelihara fauna, bertani, dan sebagian segi dari sejarah kealaman (Bilqrami, 1989).

Dari dua pendapat yang saling bertolak belakang, maka penulis akan mengambil jalan tengah, mengkompromikan dua pendapat di atas. Artinya penulis akan menyimpulkan bahwa, meski di madrasah Nizamiyah ini diajarkan materi-materi umum, namun materi-materi agama (ilmu syari'ah) porsinya jauh lebih banyak dan mendominasi. Hal ini bisa jadi selaras dengan motif pendirian madrasah yang awal mulanya, selain merupakan bentuk perkembangan pendidikan Islam yang semakin mengalami kemajuan, maka di sisi lain ada unsur politikideologis dalam pendirian madrasah ini. Tentu materi-materi umum dirasa tidak akan selaras dengan misi yang menjadi motif pendirian madrasah yang kedua itu, yakni politik-ideologis.

Adapun metode pembelajaran di Madrasah Nizamiyah adalah dengan menggunakan metode ceramah dan tanya jawab. Metode ini termasuk dari model pembelajaran langsung. Sedangkan metode lain yang digunakan di Madrasah Nizamiyah adalah metode diskusi, koresponden jarak jauh, dan rihlah ilmiah. Metode ini merupakan bagian dari model pembelajaran berbasis masalah dan kontekstual (Karomah, 2019). 


\section{Madrasah Nizamiyah Sebagai Lembaga Pendidikan}

Tak ada yang bisa memungkiri bahwa madrasah Nizamiyah ini merupakan purwarupa lembaga pendidikan Islam di waktu itu. Sebuah prototipe yang sangat ideal, terbesar, terkenal dan sangat membanggakan dunia Islam, khususnya dalam bidang pendidikan Islam. Hal ini terjadi, tidak lepas dari peran seorang wazir Nizam al-Mulk, yang dikatakan bahwa beliau salah satu orang yang sangat cinta akan ilmu pengetahuan, dan memiliki keinginan yang kuat guna mencerdaskan umat Islam.

Madrasah Nizamiyah, tidak hanya sediakan kitab-kitab di bibliotek, pemberian bea siswa serta asrama mahasiswa, buat pengeluaran operasional madrasah ini, Nizam al-Mulk sediakan wakaf terdiri dari pasar yang dibentuk pas di depan madrasah itu, kebun-kebun( iqarat), sebagian bangunan tempat tinggal( amakin) yang diperuntukkan untuk tamu daan aktivitas madrasah yang besar. Jumlah pemasukan yang diperoleh dari wakaf madrasah itu menggapai 15. 000 dinar setahun. Jumlah ini lumayan buat menutupi seluruh pengeluaran honor para guru serta pengeluaran hidup mahasiswa, meliputi santapan, baju, dan seluruh kebutuhan pokok mereka (Ramayulis, 2011).

Sebagai lembaga pendidikan Islam yang khas dengan keagamaannya, madrasah Nizamiyah telah menjadi model awal percontohan madrasah-madrasah di waktu itu. Tak ayal jika dari madrasah Nizamiyah ini, muncul pula madrasah-madrasah yang serupa di berbagai daerah. Tentu hal ini sedikit banyak dipengaruhi oleh madrasah yang ada di pusat kota Baghdad itu.

Hasan Abd al-A'la menyebutkan dengan adanya madrasah Nizamiyah di Baghdad, pendidikan Islam mengalami pertumbuhan dan perkembangan. Madrasah secara resmi diatur oleh pemerintah sesuai dengan peraturan dan ketentuan yang berlaku (Ramayulis, 2011).

Simpulan akhir yang dapat penulis susun bahwa eksistensi madrasah Nizamiyah sebagai lembaga pendidikan tentu sudah tidak diragukan lagi. Artinya madrasah ini telah berhasil menjadi tempat belajar yang didatangi para pembelajar dari seluruh penjuru dunia dan mampu menjadi salah satu role model kelembagaan yang dapat ditiru sampai saat ini, baik dari sisi kurikulum, manajemen, metode pembelajaran maupun tenaga pendidiknya.

\section{Madrasah Nizamiyah: Perang Politik-ideologi}

Madrasah Nizhamiyah didirikan pada masa pemerintahan dinasti Saljuq. Bagi Jurji Zaidan, dinasti Saljuq dibagi ke dalam 5 babakan sejarah dinasti, ialah Saljuq Raya, Saljuq di Kirman, Saljuq di Syam, Saljuq di Iraq serta Kurdistan, dan Saljuq di Rum ataupun Asia Kecil. Di antara dinasti-dinasti tersebut, Saljuq Raya yang jadi dinasti yang mempunyai kekuasaan serta daerah sangat besar. Dinasti ini bermula dari kesultanan Tughril bek. Seluruh dinasti tersebut merupakan pendukung aliran ahl al-sunnah wa al-jama' ah ataupun kerap diucap kalangan sunni (Asari, 1994).

Kata sunni berasal dari bahasa arab yang dinisbatkan pada kata sunnah. Secara etimologis, sunnah berarti tradisi ataupun adat kerutinan yang sudah melembaga di warga. Sebutan sunnah umumnya berkaitan dengan 3 kajian riset Islam, ialah hadits, teologi Islam serta politik Islam.

Di dalam kajian hadits, sunnah berarti segala sesuatu yang datang dari Nabi Muhammad yang meliputi ucapan, perbuatan pengakuan (taqrir) dan sesuatu yang bermaksud dikerjakan oleh Nabi (Ramli, 2011). Ini berarti sunnah merupakan tradisi yang telah dikerjakan oleh Nabi dan diteruskan oleh para salaf yang shaleh. Dalam batasan teologi Islam (kalam), sunnah berarti keyakinan yang didasarkan pada dalil nali. Jadi, bukan semata-mata bersandar pada pemahaman 
akal. Dan memang, Islam adalah agama yang harus dikaji dengan menggunkan sumber naqli (alQur'an dan hadits) dan dianalisa dengan akal (Nasr, 1996). Pelopor sunnah dalam teologi Islam adalah Abu Hasan al-Asyari (260-330 H/873-947 M) di Mesopotamia dan Abu Mansur alMaturidi (w. 944 M) di Samarkand (Nasution, 1986).

Adapun sunnah dalam pengertian kajian politik Islam berarti mengikuti jejak yang ditinggalkan Rosulullah dan Khulafaur Rasyidin. Mereka yang mengikuti jejak tersebut menganui ide persatuan (jama'ah) dengan cara permusyawaratan (musyawarah), dan karenanya mereka disebut ahl al-sunnah wal-jama'ah. Nourouzzaman Shiddiqi mengatakan bahwa sunni adalah nama bagi kelompok muslim pendukung sunnah dalam pengertian hadits, teologi dan politik Islam. Kadang kala kaum Sunni juga disebut sebagai muslim ortodoks, yang menjadi oposan bagi kaum Syiah dan khawarij (Idi, 2006).

Pada tahun 447 H/1055 M, orang-orang Saljuq yang dipimpin Tughril bek memasuki Baghdad dan membantai orang-orang Buwaihi yang beraliran Syi'ah yang secara turun-temurun telah menguasai dinasti Abbasiyah. Dinasti Buwaihi sendiri kali pertama menguasai Baghdad pada tahun $945 \mathrm{M}$ ketika di bawah kepemimpinan Ahmad ibn Buwaihi yang bermadzhab Syi' ah dalam fiqih dan mu'tazilah dalam teologi. Namun mereka hanya mampu menguasai Baghdad sampai tahun $1055 \mathrm{M}$, yang merupakan tahun kedatangan orang-orang Saljuq.

Tughril Bek dengan bani Saljuq menguasai Baghdad sampai tahun 445 H/1063 M. Selama masa kekauasaan itu, Tughril Bek dibantu oleh perdana menteri yang bernama Abu Nasr Muhammad ibn Mansur al-Kunduri (416 H/1016 M s/d 456 H/1056 M) yang merupakan seorang mu'tazili. Orang mu'tazili selalu bersikap keras terhadap kaum Asy'ariyah-Syafi'iyah. Bahkan suatu kali al-Kunduri pernah melakukan pengusiran dan penganiayaan kaum Asy'ariyah. Di antara tokoh Asy'ariyah yang pernah ditangkap dan dipenjarakan oleh al-Kunduri adalam Imam al-Qusayri dan Imam al-Juwaini. Di samping itu, selama empat tahun (dari 451-455 H) al-Kunduri mengutuk dan melarang Asy'ariyah di setiap khutbah Jum'at. Al-Kunduri memang seorang yang sangat fanatik dengan mu'tazilah. Akan tetapi, sikap fanatiknya tidak diketahui oleh Tughril Bek yang seorang Sunni. Hal itu membuktikan bahwa betapa lemahnya kontrol dari Tughril Bek terhadap perdana menterinya, dan betapa besarnya kepercayaan yang diberikan Tughril Bek kepada perdana menterinya itu. Kejadian yang seperti ini bisa jadi disebabkan oleh gaya kepemimpinan laissez faire yang nampak pada Tughril Bek ketika menjabat sebagai pemimpin. Kaitannya dengan kepemimpinan, tentu pada tiap-tiap diri seorang pemimpin itu dilatarbelakanagi oleh beragam faktor, bisa karena genealogi, sosial, pendidikan, geografi dan lain sebagainya (Mahfud Ifendi, 2020).

Tughril Bek meninggal dunia pada 8 Ramadhan 455 H/1055 M tanpa meninggalkan seorang putra sekalipun. Sepeninggalnya, terjadi perebutan kekuasaan di atara dua kubu. Kubu pertama dipimpin oleh Sultan Alp Arselan yang didukung oleh Nizam al-Mulk, sedangkan kubu kedua dipimpin oleh Sulaiman bin Caghril Bek yang dibantu al-Kunduri (Hasan Ibrahim Hasan, 1976). Dari perebutan kekuasaan itu, Alp Arselan berhasil menjadi penguasa dinasti Saljuq, yang kemudian mengangkat Nizam al-Mulk sebagai perdana menterinya.

Sejak berkuasa dan naik tahta, Sultan Alp Arselan (berkuasa 455-465 H/ 1062-1072 M) memberi angin yang sangat menguntungkan bagi penganut Asy'ariyah. Ini dikarenakan Nizam al-Mulk, perdana menterinya, adalah orang yang beraliran Asy'ariyah-Syafi'iyah. Nizam al-Mulk dapat dikatakan sebagai musuh utama al-Kunduri yang beraliran mu'tazili. Dalam pandangan Marshall G.S Hodgson, Nizam al-Mulk adalah satu-satunya perdana menteri yang berhasil menggantikan al-Kunduri. Terbukti, Nizam al-Mulk menjabat sebagai perdana menteri bagi 
dinasti Saljuq selama dua masa kesultanan, yaitu masa sultan Alp Arselan dan Malik Syah (berkuasa 465-485H/1072-1092 M) (Hodgson, 1974). Selama Nizam al-Mulk berkuasa sebagai perdana menteri, sistem Asy'ariyah ditetapkan dan diakui sebagai teologi Islam kaum Sunni, sekalipun tidak dinyatakan sebagai suatu kewajiban (Gibb, 1983).

Teologi Asy'ariyah memang mendapatkan dukungan dari dinasti Saljuq. Salah satu wujudnya adalah teologi ini diajarkan di madrasah Nizamiyah. Lebih dari itu, melalui madrsahmadrasah tersebut telah dihasilkan para ulama Asy'ariyah yang paling senantiasa berupaya mengembangkan paham Sunni. Dengan demikian, madrasah Nizamiyah menjadi bagian dari kebijakan Nizam al-Mulk untuk mencipatakan persatuan di kalangan kaum sunni (Idi, 2006).

Menurut Ira M. Lapidus, Nizam al-Mulk sebenarnya menghendaki adanya kontrol pemerintah terhadap gerakan kaum Sunni. Dalam hal ini, Nizam al-Mulk bermaksud menggunakan aliran hukum (fiqih Syafi'i) dan aliran teologi (paham Asy'ariyah) sebagai alat politik untuk mempengaruhi masa, karena paham Sunni merupakan paham terbesar pada waktu itu. Untuk melaksanakan maksud tersebut, Nizam al-Mulk kemudian mendirikan sejumlah madrasah yang berada di bawah kontrol pengaruhnya. Tidak mengherankan bila madrasah Nizamiyah kemudian memiliki komitmen untuk berpegang teguh pada doktrin Asy'ariyah.

Atas dasar hal tersebut, Azra melihat bahwa munculnya madrasah Nizamiyah merupakan prototipe bagi upaya kebangkitan kembali ortodoksi Sunni (Azra, 1994). Pendapat itu juga didukung oleh Nakosteen yang menyebutkan bahwa madrasah Nizamiyah selain memiliki spirit ilmu pengetahuan yang tinggi, baik untuk tujuan politik maupun agama, juga dimaksudkan untuk membentuk opini publik tentang Islam Sunni ortodoks atas Islam Syi'ah (Nakosteen, 1994). Demikainlah betapa Sunni mendapatkan perhatian dan dukungan besar dari Nizam alMulk melalui projek pembangunan madrasah Nizamiyah. Kemunculan madrasah Nizamiyah menjadi bukti atas kebangkitan kembali paham Sunni yang pada beberapa tahun sebelumnya memperoleh tekanan dari paham Syi'ah dan Mu'tazilah.

Politik akan menentukan kemajuan dan kemunduran pendidikan. Tidak peduli apa yang dicapai atau bentuk pendidikan apa pun, baik positif maupun negatif adalah bagian dari proses minat dan intrik politik. Gerakan ilmiah perubahan dan transformasi masyarakat selalu didorong oleh dukungan politik. Dalam konteks ini, politik tampaknya menjadi pendukung utama pencapaian kejayaan sistem pendidikan (Murtopo, 2014).

Selain sebagai lembaga pendidikan, yang menarik sekali menurut penulis tentang madrasah Nizamiyah ini adalah juga merupakan sebuah media untuk mempertahankan ideologi khalifah. Mengapa begitu menarik, karena dilintas sejarah pendidikan Islam, sependek pengetahuan penulis, mengatakan bahwa ini satu-satunya lembaga pendidikan yang tujuan pendiriannya ada motif lain selain mengurusi masalah pendidikan. Sehingga kajian-kajian berikutnya semakin menambah rasa penasaran bisa jadi ditemukan kasus yang sama dengan apa yang terjadi pada masa itu. Akan sangat tidak menutup kemungkinan di luar sana akan ditemukan contoh kasus madrasah atau lembaga pendidikan yang motif berdirinya tidak murni berangkat dari ide pendidikan.

\section{Kesimpulan}

Sebagaimana yang kita ketahui, madrasah Nizamiyah telah memainkan peran penting dalam sejarah peradaban Islam dalam menopang laju perkembangan pendidikan Islam. Karena memang adanya madrasah ini merupakan salah satu indikator dari majunya pendidikan Islam, kehadirannya harus dapat memberikan ruang perbedaan dibandingkan masa sebelumnya yang 
dari sisi jumlah lembaga pendidikan belum banyak bermunculan. Nah selain sebagai lembaga pendidikan, hadirnya madrasah nidhamiyah ini ternyata juga ditemukan motif lain dalam sejarah berdirinya. Apa yang telah dilakukan oleh Nizam al-Mulk atas seizin Sultan Alp Arselan, ternyata dapat mengembalikan ideologi Asy'ariyah-Syafi'iyah yang sebelumnya sempat diberangus karena memang pemimpin sebelumnya yang dibantu oleh al-Kunduri telah menganut paham Syiah dalam masalah fiqih, dan Mu'tazilah dalam urusan teologi. Dengan berhasilnya Nizam al-Mulk mengalahkan rivalnya itu lantas kemudian mendirikan madrasah ini, menandakan kebangkitan dan persatuan kembali Islam Sunni atas Islam Syi'ah dalam catatan sejarah umat Islam.

\section{DAFTAR PUSTAKA}

Aden Wijdan. (2007). Pemikiran dan Peradaban Islam. Safiria Insania Press.

Ahmad, E. R. (2015). Madrasah Nizamiyah Pengaruhnya terhadap Perkembangan Pendidikan Islam dan Aktivitas Ortodok Sunni. 2015, 127-138.

Asari, H. (1994). Menyingkap Zaman Keemasan Islam: Kajian atas Lembaga-lembaga Pendidikan. Mizan.

Azra, A. (1994). Jaringan ulama: Timur Tengah dan kepulauan Nusantara abad XVII dan XVIII: melacak akar-akar pembaruan pemikiran Islam di Indonesia. Mizan.

Bilqrami, M. H. (1989). Konsep Universitas Islam. Tiara Wacana Yogya.

Darwis, D. (2010). Dinamika Pendidikan Islam. RaSAIL.

Daulay, H. P. (2007). Sejarah pertumbuhan dan pembaruan pendidikan Islam di Indonesia (Ed. 1., ce). Kencana Prenada Media Group.

Gibb, H. A. . (1983). Islam dalam Lintasan Sejarah. Bhatara Karya Aksara.

Hasan Ahmad Mahmud dan Ahmad Ibrahim al-Syarif. (1997). al-Alam al-Islami Ashri al-Abbasi. Dar al-Fikr.

Hasan Ibrahim Hasan. (1976). Tarikh al-Islam. al-Nahdah al-Mishiriyah.

Hodgson, M. G. . (1974). The Venture of Islam. University of Chicago Press.

Idi, A. C. N.-M. 2007/01353 (L). (2006). Revitalisasi pendidikan Islam (Cet. 1). Tiara Wacana. Kaelan. (2010). Metode Penelitian Agama Kualitatif Interdisipliner. Paradigma.

Karomah, F. F. (2019). Relevansi Pembelajaran di Madrasah Nizamiyah dengan Pembelajaran pada Kariman, Volume 07 , Nomor 02 , Desember 2019| 205 Fika Fitrotin Karomah. Kariman, 07, 205-220.

Kodir, A. (2015). Sejarah Pendidikan Islam: dari Masa Rasulullah hingga Reformasi di Indonesia.

Mahfud Ifendi. (2017). Madrasah sebagai Pendidikan Islam Unggul. JALIE: Journal of Applied Linguistics and Islamic Education, 01(September), 333-355.

Mahfud Ifendi. (2020). Pesantren dan Kepemimpinan Kiai: Studi Kasus di Pondok Pesantren Mambaus Sholihin Gresik (1980-2020). MUDIR (Jurnal Manajemen Pendidikan), 2(September), 13.

Mahmud Yunus. (1990). Sejarah Pendidikan Islam. Hidakarya Agung.

Misdar, M. (2017). Sejarah Pendidikan dalam Islam. Jakarta: PT RajaGrafindo Persada.

Murtopo, A. (2014). Politik Pendidikan pada Masa Daulah Abbasiyah (Kasus Madrasah Nizamiyah di Baghdad). TA'DIB, XIX(02), 313-332.

Nakosteen, M. (1994). Kontribusi Islam Atas Dunia Intelektual Barat; Deskripsi Analisis Abad Keemasan Islam. Risalah Gusti. 
Nasr, S. H. (1996). Intelektual Islam: Teologi, Filsafat dan Gnosis. Pustaka Pelajar.

Nasution. (1988). Metode Penulisan Naturalistik Kualitatif. Tarsito.

Nasution, H. (1986). Teologi Islam: aliran-aliran sejarah analisa [dan] perbandingan (Cet. 5). Penerbit Universitas Indonesia (UI-Pr.).

Phillip. K. Hitti. (2002). Terjemahan History of the Arabs. PT Serambi Ilmu Semesta.

Ramayulis. (2011). Sejarah Pendidikan Islam: Napaktilas Perubahan Konsep, Filsafat, dan Metodologi Pendidikan Islam dari Era Nabi sampai Ulama Nusantara (Cet. 1). Kalam Mulia.

Ramli, M. I. (2011). Pengantar sejarah Ahlussunah wal-Jama’ah (Cet. 1). Khalista : Lajnah Ta'lif wan Nasyr PBNU.

Suwito, \& Fauzan. (2005). Sejarah Sosial Pendidikan Islam (I). Kencana.

Ta’rifin, A. (2010). Madrasah Nizamiyah: Simbol Patronase Penguasa Sunni dalam Lembaga Pendidikan. FORUM TARBIYAT, 8(1), 73-86.

Yasin, A. F. (2008). Dimensi-dimensi Pendidikan Islam (A. Barizi (ed.); 1st ed.). UIN-Malang Press.

Zuhairini, Moh. Kasiram, Abdul Ghofir, Tajdab, M. F. dan M. U. (2013). Sejarah Pendidikan Islam (XII). Bumi Aksara. 